\title{
Trade and Infrastructure in the Belt and Road Initiative: A Gravity Analysis Based on Revealed Trade Preferences
}

\author{
Cristina Di Stefano ${ }^{1}\left(\mathbb{D}\right.$, P. Lelio Iapadre ${ }^{1,2, * \mathbb{C}}$ and Ilaria Salvati ${ }^{3}$ \\ 1 Laboratory on Globalisation, Innovation and Local Development, Dipartimento di Ingegneria Industriale e \\ dell'Informazione e di Economia (DIIIE), University of L'Aquila, 67100 L'Aquila, Italy; \\ cristina.distefano@univaq.it \\ 2 United Nations University Institute on Comparative Regional Integration Studies (UNU-CRIS), Potterierei 72, \\ 8000 Brugge, Belgium \\ 3 Independent Researcher, 67100 L'Aquila, Italy; ilaria.salvati@hotmail.com \\ * Correspondence: lelio.iapadre@univaq.it; Tel.: +39-0862-434866
}

\section{check for} updates

Citation: Di Stefano, Cristina, P. Lelio Iapadre, and Ilaria Salvati. 2021. Trade and Infrastructure in the Belt and Road Initiative: A Gravity Analysis Based on Revealed Trade Preferences. Journal of Risk and Financial Management 14: 52. https:// doi.org/10.3390/jrfm14020052

Academic Editor: Maria Cipollina

Received: 23 November 2020

Accepted: 22 January 2021

Published: 26 January 2021

Publisher's Note: MDPI stays neutral with regard to jurisdictional claims in published maps and institutional affiliations.

Copyright: (C) 2021 by the authors. Licensee MDPI, Basel, Switzerland. This article is an open access article distributed under the terms and conditions of the Creative Commons Attribution (CC BY) license (https:// creativecommons.org/licenses/by/ $4.0 /)$

\begin{abstract}
This paper aims at investigating whether and how the intensity of trade between a pair of countries changes when they experience improvements in their infrastructural systems. We carry out our analysis considering countries participating in the Belt and Road Initiative (BRI), a project specifically designed to promote infrastructural connectivity and therefore boost trade among the countries involved. Our empirical strategy relies on a particular specification of the gravity model, in which the dependent variable consists in an index of revealed trade preferences, calculated by comparing the actual value of trade flows between two countries with their expected value, proportional to the two countries' total trade. Such methodology allows us to estimate bilateral trade intensity without resorting to the traditional "size" variables of the gravity model, taking the entire network of multilateral trade into account. We then study the possible impact of an improvement in infrastructure on a 'gravity-adjusted' measure of trade preferences, given by the residuals of our first estimations. Our results indicate that bilateral preferences among BRI countries will intensify inasmuch as they succeed in coordinating their infrastructural projects.
\end{abstract}

Keywords: gravity model; geography of trade; Belt and Road Initiative; infrastructure

\section{The Belt and Road Initiative and the Role of Infrastructure}

In 2013, the Chinese government announced the launch of a new project known as 'The Belt and Road Initiative' (BRI) to improve connectivity between Asia, Europe, and Africa. In 2015, China's National Development and Reform Commission (NDRC) of the Ministry of Commerce and Ministry of Foreign Affairs defined frameworks, principles, and actions of the initiative by releasing the Blueprint 'Vision and Actions on Jointly Building the Silk Road Economic Belt and 21st Century Maritime Silk Road'. The idea behind the program was that of a "win-win cooperation that promotes shared development and prosperity" ${ }^{\prime 1}$ and favors integration and cultural exchange among regions. The BRI encompasses two main projects: the Silk Road Economic Belt (SREB) and the 21st Century Maritime Silk Road (MSR). The former connects China to Central and South Asia and onward to Europe; the latter connects China to the nations of South East Asia, the Gulf countries, East and North Africa, and Europe. The BRI does not aim at strengthening only one route, but it envisages six economic corridors with overland and maritime elements, consisting in networks of rail routes, roads, waterways, pipelines, and ICT infrastructure (Das 2017); these corridors are: (1) the China-Mongolia-Russia Economic Corridor; (2) the New Eurasian Land Bridge; (3) the China-Central Asia-West Asia Economic Corridor; (4) the China-Indochina Peninsula Economic Corridor; (5) the China-Pakistan Economic

1 See Shaoshi (2015, p. 4). 
Corridor; and (6) the Bangladesh-China-India-Myanmar Economic Corridor. While infrastructure connectivity is the most relevant objective of the project, others are coordination of development strategies and policies, trade facilitation to ensure "unimpeded trade", financial integration, and people-to-people exchange. The BRI is structured as an open initiative that allows every country to participate, and there is no official list of countries involved. Up to March 2020, 138 countries had signed the Memorandum of Understanding (MoU) with China.

In order for the BRI to succeed, policy measures (e.g., harmonization of technical standards, single clearance mechanism, monitoring, and promotion activities) are complementary to building new infrastructure, since they can improve management of the transport network (Kunaka and Carruthers 2014). For this reason, the Chinese government has also integrated different existing regional cooperation mechanisms as the Shanghai Cooperation Organization (SCO), ASEAN (Association of Southeast Asian Nations) Plus China $(10+1)$, China-ASEAN Expo, Asia-Pacific Economic Cooperation (APEC), and Greater Mekong Sub-region Economic Cooperation (GMS) (Yu 2017) and has established the Asian Infrastructure Investment Bank (AIIB) and the Silk Road Fund to help involved countries funding investment in infrastructure. However, although China presents the initiative as a win-win project, there are increasing concerns on the capability of the other countries involved to cope with the debts incurred to finance the new infrastructure (Hurley et al. 2018).

In order to exploit the true potential of the initiative, infrastructure investment is not enough: trade facilitation reforms and policy actions able to improve infrastructure management along the corridors are needed (De Soyres et al. 2018), since trade facilitation performance, i.e., the performance of the overall supply chain (Grainger and McLinden 2013) along the BRI corridors is below the world average (Bartley Johns et al. 2018). This is also confirmed by Baniya et al. (2020) who stress the importance of complementing BRI infrastructure projects with lower border delays, better management of corridors, and higher trade cooperation.

In terms of economic development, benefits deriving from investment in transportation infrastructure are well documented in the literature (e.g., Redding and Turner 2015). Some authors have also focused on the BRI, analyzing the association between transport infrastructure, trade expansion, and economic development. The increase in China's exports towards BRI countries did not start with the BRI announcement, but it was already in progress in the early 2000s (Constantinescu and Ruta 2018): the intraregional share of BRI countries' total exports rose from 30.6\% in 1995 to $43.3 \%$ in 2015 (Boffa 2018).

De Soyres et al. (2018) analyzed the impact of the transport infrastructure projects envisaged by the BRI, arguing that they will significantly reduce shipment times and trade costs not only in the BRI countries but also in the rest of the world. Results of the study show that countries located along the corridors where projects will be realized would record the largest positive impacts and may be able to experience a reduction in shipment time and trade costs by up to $11.9 \%$ and $10.2 \%$, respectively. In a following study, De Soyres et al. (2020) estimated that carrying out the BRI transport infrastructure projects may increase gross domestic product by up to $3.4 \%$ for the countries involved and by up to $2.9 \%$ for the world. However, the high costs of infrastructure may determine a negative effect on welfare (defined as real consumption) in some countries. Moreover, Yang et al. (2020) show a possible increase in welfare and economic growth connected with infrastructure investment in Asia (particularly in Southeast Asia) and in Russia. Their analysis also identifies a possible positive effect on GDP growth in most areas of the rest of the world.

Recognizing the strong connection that exists among infrastructure, trade, and economic development, the objective of this paper is to investigate how an increase in the infrastructure endowment of countries participating in the BRI may impact the intensity of their bilateral trade, relative to their total shares of world trade. In our analysis, we start with a particular specification of the gravity model in which the dependent variable is an index of 'revealed trade preferences', i.e., a measure of the intensity of trade between 
a couple of countries, relative to the entire network of world trade. We then take the estimated residuals from this exercise as a 'gravity-adjusted' measure of revealed trade preferences and use it as the dependent variable of a second regression, which focuses on the relationship between bilateral trade intensity and infrastructure.

The rest of the paper is organized as follows: in the next paragraph we discuss the possible role of trade intensity indices in the gravity equation, and the approach we follow to study the effects of infrastructure on the geographic distribution of trade flows. In Section 3, we present the revealed trade preference (RTP) index used for our estimations. After a descriptive analysis of RTP indices in the six corridors encompassed by the BRI (Section 4), we present the results of our econometric exercise (Section 5). The last paragraph is dedicated to the conclusions.

\section{Bilateral and Multilateral Trade Costs in the Gravity Model}

Since the seminal papers by Tinbergen (1962) and Pöyhönen (1963), several specifications of the gravity model of international trade have been proposed in the literature (Yotov et al. 2016). In its simplest versions, the gravity equation shows how the value of trade flows between two countries is directly related to their economic size and inversely related to their distance, and/or to other factors, such as trade policies, affecting the cost of bilateral commerce.

Initially, the empirical success of the gravity model in explaining the geographic distribution of trade was accompanied by a lack of theoretical support. However, after the work made by Anderson (1979), several authors introduced a range of theoreticallygrounded variants of the model (e.g., Bergstrand (1985, 1989); Deardorff (1998); Eaton and Kortum (2002)). Among others, Anderson and Van Wincoop (2003) presented an augmented version of the gravity equation including multilateral trade resistance (MTR) terms. These terms capture the idea that trade flows between two countries depend not only on their bilateral trade resistance (i.e., on trade costs due to distance and other bilateral barriers to trade), but also on the costs faced by each country in trading with all its other partners (MTR). Neglecting MTR in gravity equation is considered a "gold medal mistake" (Baldwin and Taglioni 2006), which can be prevented through various econometric techniques (Yotov et al. 2016). Feenstra (2004) proposed the use of countryspecific fixed effects, Baier and Bergstrand (2009) accounted for MTR through a first-order Taylor series approximation, and, more recently, Patuelli et al. (2016) and Metulini et al. (2018) suggested the use of origin and destination-specific spatial filters.

Among recent papers that study the relationship between trade and infrastructure, Donaubauer et al. (2018) adapted the method proposed by Feenstra (2004) in analyzing the impact of infrastructure on bilateral trade among 150 developed and emerging economies. Lee (2018) and Kim and Mariano (2020), too, chose the same approach studying respectively the impact of an increase in infrastructure on China's trade with Central Asian countries, and the impact of infrastructure quality on bilateral trade relations in the Central Asia Regional Economic Cooperation (CAREC) region. Herrero and Xu (2017) focused on the impact of infrastructure investment on trade in countries involved in the BRI, following the model specification proposed by Baier and Bergstrand (2009) and the same methodology was adopted by Hussain et al. (2019) in their analysis of the relationship between exports and infrastructural indicators in 46 Asian countries.

In this paper, we propose a solution to the MTR issue relying on a trade intensity index. Unlike traditional specifications of the gravity equation, in fact, our dependent variable is not the value of trade flows between each pair of countries. Instead, we use the revealed trade preference (RTP) index proposed by Iapadre (2006). As we will better explain in the next paragraph, this index allows to evaluate the intensity of trade between pairs of countries, comparing the actual value of their bilateral trade flows with the hypothetical value they would have if each country traded with the other in proportion to their world trade shares. This 'geographic neutrality' benchmark reflects an abstract frictionless world in which trade costs, although influencing the total value of trade flows, do not affect their 
geographic distribution (Kunimoto 1977). The usefulness of RTP indices for solving the MTR issue stems from the fact that they show the degree of reciprocal preference between two trading partners in relative terms: the intensity of trade between a pair of countries depends not only on their reciprocal trade flows, but also on the entire network of trade linkages with and among all their partners (Iapadre and Tironi (2009); Iapadre and Tajoli (2014)). Thus, any reduction in bilateral resistances or increase in multilateral resistances determines an increase in bilateral revealed trade preferences, relative to the rest of the world. By using RTP indices as the dependent variable in the gravity equation, we do not need to introduce multilateral resistance terms, since they are already reflected in the index. In other words, RTP indices may be seen as an inverse measure of bilateral relative to multilateral trade costs, following an approach similar to the trade cost measure proposed by Novy (2013).

Moreover, relying on RTP indices allows us to exclude from our gravity equation the independent variables connected with country size, as they are already included in the RTP index formula, which allows to focus the estimates exclusively on distance and other trade cost variables. Indeed, as already argued, the RTP index reveals to what extent two countries' actual bilateral trade differs from the hypothetical value that it would reach, if it were proportional to their total trade with the rest of the world (neutrality benchmark), which depends on both their economic size and their degree of international openness. Accordingly, by adopting the RTP index, we are able to overcome another problem of traditional specifications of the gravity model, that is related to the well-known inverse relationship between the trade-to-GDP ratio and country size (Frankel 1997; Anderson 2011). The use of GDP as a "size" variable among the regressors of traditional gravity equations implicitly assumes a proportional relationship between a country's total trade and GDP, which is at odds with the fact that the relative importance of international trade is higher in small economies than in large ones.

The usefulness of trade intensity indices in the analysis of bilateral trade flows was already recognized in the literature, for instance by Leamer and Stern (1970), Drysdale and Garnaut (1982), Anderson and Norheim (1993), and Frankel (1997). Moreover, these indices have already been adopted in gravity models, as for example by Gaulier et al. (2004) and by Zhang and Van Witteloostuijn (2004). In the first paper, the authors analyze the regionalization of international trade by assessing the impact of regional integration arrangements on trade flows. They replicate the traditional gravity estimation based on bilateral trade flows also adopting an index of bilateral trade intensity as the dependent variable of the equation. The authors recognize that a model based on trade intensity index is useful to focus the estimation on bilateral distance factors (geographic, cultural, etc.). Zhang and Van Witteloostuijn (2004) study China's trade linkages and use export and import intensities to examine changes in the geographic distribution of Chinese trade in the period 1993-1999. They argue that the use of an intensity index is preferable to the value of trade flows, since this indicator is not influenced by changes in country-specific factors (e.g., the countries' international openness, exchange rate, and price level). The latter equally impact all bilateral trade flows of the country with its trade partners and affect the total volume of trade but not necessarily its geographic distribution.

Our gravity equation will relate RTP indices to a set of 'dyadic' (country-pair-specific) variables, such as distance, that are traditionally considered as important determinants of bilateral trade costs. We will use only dyadic regressors, so as to obtain an estimate of what would be the geographic distribution of bilateral RTPs if they depended only on bilateral trade costs, excluding any country specific variable.

The following step will be based on the resulting estimation residuals, which we consider as a measure of 'gravity-adjusted' RTPs, in which the underlying benchmark is no longer the abstract frictionless world of the geographic neutrality threshold, but a gravity-adjusted world in which, given the total trade size of all countries, the geography of bilateral trade (relative to multilateral trade) is affected only by differences in relative bilateral trade costs, as measured by dyadic trade cost variables and not by non-dyadic country-specific variables. Hence, a positive (negative) estimation residual will measure the 
extent to which actual RTPs go beyond (lie below) what predicted by our gravity equation, revealing the possible influence of country-specific variables. We will then use these estimation residuals as the dependent variable of a second equation, in order to explore the role of each country's infrastructure endowment in explaining 'gravity-adjusted' RTPs, and better understand the expected impact of BRI on the network of international trade flows.

\section{Revealed Trade Preference Indices}

As anticipated, our analysis focuses on the intensity of bilateral trade between countries. Specifically, for each pair of countries, $i$ and $j$, we measure a revealed total trade (exports plus imports) preference index $\left(R T P_{i j}\right)$ following Iapadre and Tajoli (2014). More in detail:

$$
R T P_{i j}=\left(H I_{i j}-H E_{i j}\right) /\left(H I_{i j}+H E_{i j}\right)
$$

$H I_{i j}$ is the "homogeneous" bilateral trade intensity index, measured as the ratio between a partner country's share of the reporting country's total trade $\left(S_{i j}\right)$ and the former's share of total trade from the rest of the world $\left(V_{i j}\right)$ :

$$
H I_{i j}=S_{i j} / V_{i j}=\left(T_{i j} / T_{i w}\right) /\left(T_{o j} / T_{o w}\right),
$$

where $T$ is total trade, $w$ denotes the world, and $o$ refers to the 'rest of the world', i.e., the entire set of country $i$ 's trade partners except for partner $j$.

$H E_{i j}$ is complementary to $H I_{i j}$ and it is the homogeneous extra-bilateral trade intensity index, calculated as follows:

$$
H E_{i j}=\left(1-S_{i j}\right) /\left(1-V_{i j}\right)
$$

The RTP index ranges between minus one and one. An indicator equal to one signals an absolute preference from $i$ to $j$, meaning that the former trades exclusively with the latter; on the contrary, the index takes value minus one if $i$ does not trade with $j$. Finally, the indicator is equal to zero when trade between the two countries is equal to the geographic neutrality benchmark. Moreover, since it is based on total trade, $R T P_{i j}$ is equal to $R T P_{j i}$.

The formula used to calculate revealed trade preferences is more complex than traditional indicators of trade intensity, modelled on Balassa's specialization indexes. Such increased complexity, however, allows solving some statistical problems typical of traditional indicators (Iapadre 2006). Furthermore, as already underlined, this index fits well in the multilateral logic of gravity models, since trade intensity between two countries does not depend exclusively on their reciprocal exchanges but also on the whole international trade network.

RTP indices can also be interpreted as providing a preliminary rough estimate of unexploited bilateral trade potential. In fact, any deviation from zero reflects the impact of distance and other factors likely to affect (positively or negatively) trade between two countries. For instance, if country $i$ were to record a negative RTP indicator with country $j$, that would imply that total trade (exports plus imports) of the former towards the latter is lower than the one that would be recorded in a geographic neutrality scenario. The gap between the RTP indicator and zero would represent unexploited bilateral trade potential between $i$ and $j$.

However, the neutrality benchmark of a frictionless world is too abstract, since it assumes the irrelevance of distance and any other source of trade cost. Substantially significant untapped trade potentials can only be detected by adjusting the benchmark for the possible role of bilateral trade costs (relative to MTR). Then, in Section 5, we will estimate a 'gravity-adjusted' benchmark, which takes into account not only the trade size of all countries (as in the unadjusted neutrality benchmark), but also distance and other dyadic variables that can affect bilateral trade costs, relative to MTR. The differences between actual and 'gravity-adjusted' RTP indices, i.e., the estimated residuals of our gravity equation, will be considered as a more meaningful measure of untapped trade potential, which could be affected by the quality of infrastructure and other country-specific (non-dyadic) variables. This is the hypothesis which we will test with our second estimation. 


\section{Data and Descriptive Analysis}

Since the area covered by the BRI is not precisely defined, this paper focuses on those countries directly located along the geographical "corridors" encompassed by the initiative, following De Soyres et al. (2018). Table 1 provides a list of the 71 countries considered.

Table 1. Economies located along the Belt and Road Initiative (BRI) corridors.

\begin{tabular}{|c|c|c|}
\hline Region & BRI Economies & Total \\
\hline East Asia and the Pacific & $\begin{array}{l}\text { Brunei, Cambodia, China, Hong Kong (China), Indonesia, Lao, Malaysia, Mongolia, Myanmar, } \\
\text { Philippines, Singapore, Taiwan (China), Thailand, Timor-Leste, Vietnam }\end{array}$ & 15 \\
\hline Europe and Central Asia & $\begin{array}{c}\text { Albania, Armenia, Azerbaijan, Belarus, Bosnia and Herzegovina, Bulgaria, Czech Republic, Croatia, } \\
\text { Estonia, Georgia, Greece, Hungary, Kazakhstan, Kyrgyz Republic, Latvia, Lithuania, Macedonia, } \\
\text { Moldova, Montenegro, Poland, Romania, Russia, Serbia, Slovak Republic, Slovenia, Tajikistan, } \\
\text { Turkey, Turkmenistan, Ukraine, Uzbekistan. }\end{array}$ & 30 \\
\hline South Asia & Afghanistan, Bangladesh, Bhutan, India, Maldives, Nepal, Pakistan, Sri Lanka. & 8 \\
\hline Middle East and North Africa & $\begin{array}{c}\text { Bahrein, Egypt, Djibouti, Iran, Iraq, Israel, Jordan, Kuwait, Lebanon, Oman, Qatar, Saudi Arabia, } \\
\text { Syria, United Arab Emirates, West Bank and Gaza, Yemen. }\end{array}$ & 16 \\
\hline Sub-Saharan Africa & Kenya, Tanzania & 2 \\
\hline
\end{tabular}

Note: countries are grouped based on the regions identified by the World Bank. Source: De Soyres et al. (2018).

We use trade data from the IMF-DOTS database complemented with those from WITSComtrade. Having a set of 71 countries, we should be able to identify 2485 bilateral trade flows; nevertheless, due to missing data, we are able to measure bilateral trade preference indexes for 1816 pairs of countries. The year considered is 2016 (three years after the official launch of the BRI), which was selected as it minimizes the number of missing data.

The RTP has an average value of -0.298 , signaling that, in general, BRI countries do not reveal reciprocal trade preferences (Table 2). In fact, the average trade value measured between country pairs is lower than the one that would be recorded in the benchmark scenario of geographic neutrality. However, minimum, maximum, and standard deviation values indicate a high heterogeneity in trade intensity across country pairs. The RTP ranges from -0.999 to 0.995 ; the pair with the lowest value is that of Iraq and Nepal, while the pair of countries with the highest indicator is Bhutan and India.

Table 2. The revealed trade preference (RTP) index: summary statistics.

\begin{tabular}{cccccc}
\hline & Mean & Std. Dev. & Min. & Max. & Obs \\
\hline RTP & -0.298 & 0.605 & -0.999 & 0.995 & 1816 \\
\hline
\end{tabular}

More in detail, we present the bilateral preferential trade links (RTPs) for the six corridors encompassed by the BRI. Looking at the China-Mongolia-Russia Economic Corridor (CMREC) (Table 3), the intensity of bilateral trade between China and Mongolia is high, and Russa and Mongolia, too, show a strong trade preference. It is also interesting to note that the value of the index between China and Russia is not as high as expected, given that the two countries share a long border.

Table 3. RTP index for countries in the China-Mongolia-Russia Economic Corridor (CMREC).

\begin{tabular}{cccc}
\hline RTP & China & Mongolia & Russia \\
\hline China & - & - & - \\
Mongolia & 0.84 & - & - \\
Russia & 0.13 & 0.79 & - \\
\hline
\end{tabular}

Revealed trade preferences are strong also between some of the countries located along the New Eurasian Land Bridge (NELB) (Table 4). In particular, intensity of bilateral trade is very high between Russia and Belarus and Russia and Kazakhstan.

The China-Indochina Peninsula Economic Corridor (CICPEC) connects China and the countries of the Association of South-East Asian Nations (ASEAN). As expected, the RTP 
indicator reveals a preference between almost all the countries (RTP index is negative only between Myanmar and Cambodia) (Table 5), which is not only due to their geographical proximity. In fact, in 1992 the ASEAN countries signed an initial agreement aimed at establishing a free trade area and, despite slow progresses, intra-ASEAN tariffs have been significantly reduced in the following decades ${ }^{2}$. Moreover, in 2004, China and the ASEAN countries signed an agreement to promote an easier movement of goods, later extended also to services in 2007. This process led to the creation of the ASEAN-China Free Trade Area (ACFTA), active since 1 January 2010.

Table 4. RTP index for countries in the New Eurasian Land Bridge (NELB).

\begin{tabular}{cccccc}
\hline RTP & Belarus & China & Kazakhstan & Poland & Russia \\
\hline Belarus & - & & & & \\
China & -0.48 & - & - & - & - \\
Kazakhstan & 0.64 & 0.21 & 0.03 & 0.44 & - \\
Poland & 0.57 & -0.49 & 0.90 & & \\
Russia & 0.97 & 0.13 & &
\end{tabular}

Table 5. RTP index for countries in the China-Indochina Peninsula Economic Corridor (CICPEC).

\begin{tabular}{|c|c|c|c|c|c|c|c|c|}
\hline RTP & Cambodia & China & Laos & Malaysia & Myanmar & Singapore & Thailand & Vietnam \\
\hline Cambodia & - & & & & & & & \\
\hline China & 0.26 & - & & & & & & \\
\hline Laos & 0.49 & 0.38 & - & & & & & \\
\hline Malaysia & 0.06 & 0.27 & 0.61 & - & & & & \\
\hline Myanmar & -0.72 & 0.64 & 0.95 & 0.45 & - & & & \\
\hline Singapore & 0.42 & 0.12 & 0.56 & 0.82 & 0.69 & - & & \\
\hline Thailand & 0.84 & 0.23 & 0.98 & 0.63 & 0.88 & 0.43 & - & \\
\hline Vietnam & 0.77 & 0.41 & 0.75 & 0.36 & 0.16 & 0.15 & 0.47 & - \\
\hline
\end{tabular}

In the China-Pakistan Economic Corridor (CPEC), the RTP index between the two countries is 0.43 ; being higher than the one that would be recorded in a geographic neutrality scenario, the indicator signals a trade preference between the pair of countries.

In the Bangladesh-China-India-Myanmar Economic Corridor (BCIMEC) (Table 6) the RTP index is negative only between Myanmar and Bangladesh; given the geographical proximity between the two countries, this negative value may be due to other types of trade barriers, such as the poor quality of infrastructure. The RTP index between India and China is equal to 0 , i.e., their total trade (exports plus imports) is equal to the one that would be expected in a geographic neutrality scenario.

Table 6. RTP index for countries in the Bangladesh-China-India-Myanmar Economic Corridor (BCIMEC).

\begin{tabular}{ccccc}
\hline RTP & Bangladesh & China & India & Myanmar \\
\hline Bangladesh & - & & & \\
China & 0.23 & - & - & - \\
India & 0.65 & 0 & 0.60 & - \\
Myanmar & -0.14 & 0.64 & & \\
\hline
\end{tabular}

The China-Central Asia-West Asia Economic Corridor (CCWAEC) is the widest corridor of the BRI and links China to the Arabian Peninsula (Table 7). Countries having a central geographical position in the corridor (for instance, Saudi Arabia and Yemen) present positive revealed trade preferences with almost all their trading partners. The more peripheral countries, instead, present negative values of the index (for example trade preferences are negative between Greece and 12 out of its 16 trading partners) and this is certainly influenced by their geographical position; however, a large perceived distance between countries, due for instance to political factors, can also play an important role.

2 https://asean.org/asean-economic-community/asean-free-trade-area-afta-council/. 
Table 7. RTP index for countries in the China-Central Asia-West Asia Economic Corridor (CCWAEC).

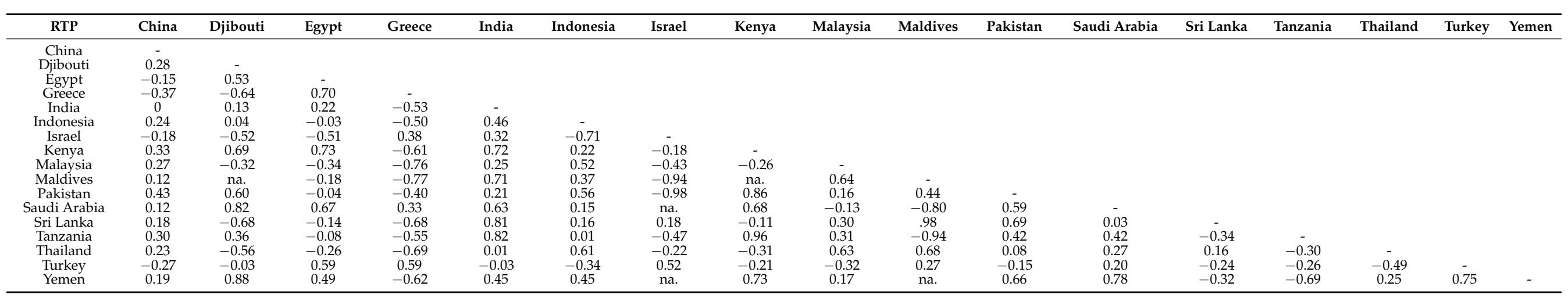




\section{Gravity-Adjusted Revealed Trade Preferences and Infrastructure: Empirical Analysis and Results}

The empirical approach adopted in this paper consists in a two-step analysis. Our main objective is to assess whether and how the intensity of trade between countries involved in the BRI is expected to change in relation to developments in the level of their infrastructure, as envisaged by the project. To specifically analyze the relationship between the quality of infrastructure and revealed trade preferences, first we estimate a measure of trade intensity that is 'gravity-adjusted', namely, a measure that is not conditioned by any country-pair specific distance-related variable which is normally considered in gravity models.

To do so, we start with a specification of the gravity equation in which the dependent variable is the revealed trade preference index already introduced, while the explanatory variables are a set of 'dyadic' (country-pair specific) variables that can affect the cost of bilateral trade, relative to trade with the rest of the world. Hence, we include all the dyadic variables commonly considered in the gravity literature to take into account the (physical and cultural) distance and the existence of trade agreements between countries, but we exclude any country-specific variable. All the independent variables are drawn from the CEPII GEoDist database, except for the FTA dummy, that we constructed based on the information about trade agreements provided by the World Trade Organization (WTO), the World Bank, and the Asian Development Bank (ADB).

Therefore, the first equation we estimate is the following:

$$
R T P_{i j}=\beta_{0}+\beta_{1} C_{C O N T I G} i j+\beta_{2} \text { COMLANG_OFF }_{i j}+\beta_{3} \text { COLONY }_{i j}+\beta_{4} \text { SMCTRY }_{i j}+\beta_{5} L O G_{-} \text {DIST }_{i j}+\beta_{6} \text { FTA }_{i j}+\varepsilon_{i j}
$$

where:

- $\quad$ CONTIG $_{i j}$ is a dummy variable that is equal to 1 if countries $i$ and $j$ are contiguous;

- COMLANG_OFF $F_{i j}$ is a dummy variable that is equal to 1 if countries $i$ and $j$ have the same official language;

- $\quad \operatorname{COLONY} Y_{i j}$ is a dummy variable that is equal to 1 if countries $i$ and $j$ share past colonial ties;

- $\quad S M C T R Y_{i j}$ is a dummy variable that is equal to 1 if countries $i$ and $j$ in the past were united in a single country;

- LOG_DIST $T_{i j}$ is the logarithm of the distance ${ }^{3}$ between countries $i$ and $j$;

- $\quad F T A_{i j}$ is a dummy variable that is equal to 1 if there is any preferential trade agreement between the two countries $i$ and $j$;

Summary statistics of the variables included in the first equation is presented in the following table (Table 8).

Table 8. Summary statistics of the variables used in Equation (4).

\begin{tabular}{cccccc}
\hline & Mean & Std. Dev. & Min. & Max. & Obs. \\
\hline RTP & -0.298 & 0.605 & 0.999 & 0.995 & 1816 \\
CONTIG & 0.058 & 0.234 & 0 & 1 & 1816 \\
COMLANG_OFF & 0.063 & 0.245 & 0 & 1 & 1816 \\
COLONY & 0.014 & 0.119 & 0 & 1 & 1816 \\
SMCTRY & 0.019 & 0.137 & 0 & 1 & 1816 \\
DIST & 4266.39 & 2659.39 & 85.94 & $11,416.28$ & 1816 \\
FTA & 0.30 & 0.458 & 0 & 1 & 1816 \\
\hline
\end{tabular}

As anticipated, the number of observations considered in the analysis is 1816, due to missing data in the matrix of bilateral trade flows. Almost one third of the pairs of countries

3 The distance between two countries is the geodetic distance evaluated through the great-circle method, that is based on geographical longitude and latitude of cities or most important agglomeration areas in term of population (Mayer and Zignago 2012). 
analyzed is linked by a preferential trade agreement, while the percentage of those sharing a common official language or past colonial ties is much lower (6.3\% and $1.4 \%$, respectively). The closest countries are Lebanon and Syria, while Belarus and Indonesia are the furthest from each other.

Table 9 presents the results of Equation (4), obtained through Ordinary Least Squares (OLS) estimations.

Table 9. Results of Equation (4).

\begin{tabular}{ccc}
\hline & Coef. & Robust Std. Err. \\
\hline CONTIG & $0.288^{* * *}$ & 0.049 \\
COMLANG_OFF & $0.198^{* * *}$ & 0.046 \\
COLONY & $0.401^{* * *}$ & 0.066 \\
SMCTRY & -0.040 & 0.055 \\
log_DIST & $-0.254^{* * *}$ & 0.019 \\
FTA & $0.420^{* * *}$ & 0.034 \\
Constant & $1.593^{* * *}$ & 0.165 \\
Observations & 1816 & \\
R-squared & 0.474 &
\end{tabular}

Our results show a significative and positive correlation between the trade intensity index and the variables CONTIG, COMLANG_OFF, COLONY, and FTA. This indicates that countries having signed a trade agreement or sharing a border, an official language, or past colonial ties have a higher relative preference in trade and vice versa. At the same time, the results from the first step of our econometric analysis confirm that there is a negative relation between two countries' trade intensity index and their geographical distance. This is in line with the vast literature using the gravity model to explore the influence of different dimensions of cross-country proximity on their bilateral trade.

Thanks to the coefficients estimated in the first equation, we are able to calculate $R T P_{i j}{ }^{*}$, that is the value $R T P_{i j}$ would have if it depended only on those dyadic variables related to geography, history and trade policies, determining the (physical or perceived) distance between two countries and affecting their relative bilateral trade costs.

The residuals of our first estimations, i.e., the differences between actual and predicted values of RTP $\left(\triangle R T P_{i j}\right)$ can be considered as a 'gravity-adjusted' measure of revealed trade preferences or, in other words, a more precise measure of untapped trade potential than the simple RTP index:

$$
\Delta R T P_{i j}=R T P_{i j}-R T P_{i j}^{*}
$$

Specifically, when:

- $\quad R T P_{i j}<R T P^{*}{ }_{i j}(\triangle R T P<0)$, the intensity of trade between $i$ and $j$ is lower than the value expected based on the explanatory variables considered in the gravity equation: there is an untapped trade potential between $i$ and $j$.

- $\quad R T P_{i j}>R T P^{*}{ }_{i j}(\triangle R T P>0)$, the intensity of trade between $i$ and $j$ is higher than expected.

We use $\triangle R T P_{i j}$ as the dependent variable in our second equation, in order to assess how the quality of infrastructure endowments influences the observed gap between $R T P_{i j}$ and $R T P_{i j}{ }^{*}$. There is not a unique measure for infrastructure in the literature. For instance, Herrero and Xu (2017) proxied transport infrastructure using transportation costs, while Kim and Mariano (2020) considered time and cost at the border crossing points; Lee (2018) measured infrastructure investment with official development flows (ODF) data and others selected different composite indices (Donaubauer et al. 2018; Hussain et al. 2019; Ramasamy and Yeung 2019). In this paper, we measure the quality of infrastructure for trade and transport in each country through a component of the Logistics Performance Index (LPI), published by the World Bank, which evaluates the quality of the service network needed for foreign trade. This Trade Logistics and Infrastructure (TLI) index ranges from 1 (weak quality) to 5 (top quality) and summarizes the level of infrastructure, customs efficiency, 
ease of trading across borders, quality of logistics services, precision in parcel tracking, and on-time delivery. ${ }^{4}$

The second equation is the following:

$$
\Delta R T P_{i j}=\beta_{0}+\beta_{1} T L I_{i}+\beta_{2} T L I_{j}+\beta_{3} T L I_{i} * T L I_{j}+\phi_{1} \eta_{c}+\varepsilon_{i j}
$$

where:

- $\quad T L I_{i}$ represents the quality of trade infrastructure in country $i$;

- $T L I_{j}$ represents the quality of trade infrastructure in country $j$;

- $T L I_{i} * T L I_{j}$ is an interaction variable we included to test whether the relation between $\triangle R T P_{i j}$ and an improvement in infrastructure in country $i(j)$ also depends on the quality of the infrastructure system of country $j(i)$;

- $\quad \eta_{c}$ is the set of country dummies, to control for any possible omitted country-specific effect. $^{5}$

In the following table (Table 10), a descriptive analysis of the variables included in the second estimation is presented.

Table 10. Summary statistics of the variables used in Equation (6).

\begin{tabular}{cccccc}
\hline & Mean & Std. Dev. & Min. & Max. & Obs. \\
\hline$\Delta R T P$ & 0 & 0.44 & -1.67 & 1.43 & 1816 \\
$T L I_{i}$ & 2.76 & 0.59 & 1.24 & 4.20 & 1816 \\
$T L I_{j}$ & 2.88 & 0.62 & 1.24 & 4.20 & 1816 \\
$T L I_{i}{ }^{*} T L I_{j}$ & 7.92 & 2.38 & 2.27 & 17.25 & 1816 \\
\hline
\end{tabular}

The country with the lowest quality of infrastructure is Syria, while the one with the highest quality is Singapore.

The results of the second step of our analysis are presented in Table 11. They show a negative and significant correlation between the quality of infrastructure of each country of the pair and the estimated gap in the trade intensity index, but also a positive and significant relation between the dependent variable and the interaction term. The latter mitigates or, in some cases, more than compensates for the negative change associated with the former. This suggests that, in trade between countries $i$ and $j$, the relation between an improvement of the infrastructure endowment only in country $i(j)$ and their bilateral trade preference also depends on the quality of infrastructure in country $j(i)$. In other words, the slopes of the regression lines between $\triangle R T P_{i j}$ and the reporter (partner) country's TLI index are different for different values of the partner (reporter) country's same indicator.

Table 11. Results of Equation (6).

\begin{tabular}{ccc}
\hline & Coef. & Robust \\
Std. Err
\end{tabular}

4 Regarding the role of trade infrastructure, we have experimented also with other indicators, such as those related to customs procedures length and costs, but we have found no evidence of a significative impact on trade intensity.

5 Since we look at bilateral revealed trade preferences, we do not distinguish between importers and exporters because both countries in each pair have both roles. Therefore, we resort to a single set of country dummies to control for specific country effects other than infrastructure endowment. 
Negative coefficients of TLI indices referred to each of the two countries can be explained by taking into account that an increase in the quality of infrastructure in a country boosts its trade with the whole rest of the world, thus reducing the weight of a specific partner. For example, if $\Delta R T P_{i j}>0$, an upgrade in the infrastructural system in country $i$ is likely to determine an increase in trade between country $i$ and the rest of the world; therefore, the bilateral trade preference of country $i$ towards country $j$ decreases, since the share of country $j$ on country $i$ 's total trade diminishes. If the improvement in the quality of infrastructure is experienced by country $j$, a similar process takes place; country $j$ is likely to increase its imports and exports with the rest of the world, and its preference towards country $i$ would decrease. However, as indicated by the significance of the interaction term, if the country experiencing improvements in infrastructure trades with a partner that, in turn, has a strong infrastructure system, the combination of the two factors can intensify their reciprocal trade preference.

For instance, let us consider a country $i$ trading with a partner $j$ having the lowest quality of infrastructure recorded, namely Syria (whose LI index is equal to 1.24) and let us suppose a unit increase in country $i$ 's LI index (reflecting an improvement in the quality of its infrastructure). If the interaction term in Equation (6) were not statistically significant, we would see a decrease in $\triangle R T P_{i j}$ by 0.165 . Nevertheless, being the interaction term significant, the decrease in $\triangle R T P_{i j}$ would be limited at 0.07 .

Conversely, let us consider a country $i$ trading with a partner $j$ having the highest quality of infrastructure recorded, namely Singapore (whose LI index is equal to 4.2) and, again, let us suppose an increase in country $i$ 's LI index equal to one. As already underlined, if the interaction term in Equation (6) were not statistically significant, in such scenario we would see a decrease in $\triangle R T P_{i j}$ by 0.165 . Instead, given the fact that the partner country's quality of infrastructure does interact with the improvement in country $i$ 's TLI, the resulting change in $\triangle R T P_{i j}$ in this second scenario would amount to +0.158 .

It is important to underline that our results refer to the relative intensity of bilateral trade flows and not necessarily to their value: following an upgrade in the infrastructural system in country $i$, for instance, the value of trade with $j$ might well increase; nevertheless, trade with the rest of the world could increase more, thus determining a decline in its relative trade preference towards $j$. These results confirm the convenience of resorting to measures of bilateral trade intensity, such as RTP indices, rather than to bilateral trade values, as by doing so we may easily control for any change in the multilateral network of trade flows.

While other authors adopted the gravity model to assess the impact of infrastructure on trade also focusing on BRI, none of them based the analysis on RTP indices. ${ }^{6}$ Herrero and $\mathrm{Xu}$ (2017) chose the model specification proposed by Baier and Bergstrand (2009) finding that an improvement in infrastructure under the BRI (evaluated as reduction in transportation costs) will enhance trade, and the European Union is the one that will benefit the most. However, they consider a unique proxy for infrastructure, not differentiating between reporter and partner country. Lee (2018) proposed a fixed effects gravity model; they analyze how much bilateral trade volume between Central Asian countries and China would change due to the infrastructure investment realized by China (under the BRI) and OECD in those countries. Results indicate that the impact of average OECD and Chinese investment to Central Asian Countries is significantly less than the impact of investment realized only by China; that is probably because OECD investment is more scattered on various sectors. However, in this case, infrastructure is evaluated only for one country of the pair and no interaction is considered.

6 A very recent exception is Yu et al. (2020), who present a difference-in-differences analysis to quantitatively evaluate the impact of the BRI on bilateral trade preferences using RTP indices. 


\section{Conclusions}

This study analyzed the influence that an improvement in the infrastructural endowment of the countries involved in the BRI could have on the geographic distribution of their trade, taking stock of the extant literature on the linkages between infrastructure, trade, and economic growth.

In our analysis, we focused on the change in bilateral trade intensity that countries participating in the BRI might experience thanks to an improved infrastructural system. We adopted a revealed trade preference index that is a size-independent measure of the relative strength of bilateral trade linkages. After employing a gravity analysis of revealed trade preferences, we assumed that the difference between the actual and the expected value of these indices may be considered as a 'gravity-adjusted' indicator of revealed trade preferences and we studied how this measure is related to the quality of the infrastructure in each country. Our results indicate that the relation between an improvement of the infrastructure endowment in one country of the pair, and its trade preference towards the partner must be evaluated also taking into account the quality of infrastructure in the latter; in fact, trade preferences are strengthened only when countries experiencing increases in their infrastructure endowments trade with countries having strong infrastructure systems. Our analysis is based on data from 2016. The model could be extended with the use of panel data; it would also be interesting to replicate the analysis differentiating among sectors.

In conclusion, the real impact that investment in infrastructure could have for the intensity of trade among BRI countries will strongly depend on the geographic distribution of investment projects. Although an improvement in infrastructure would be anyway beneficial for exploiting each country's untapped trade potential with the rest of the world, bilateral preferences among BRI countries will intensify inasmuch as they succeed in coordinating their infrastructure development projects, especially in those countries starting from a lower quality in their infrastructure endowments.

Author Contributions: All authors contributed equally to this work. All authors have read and agreed to the published version of the manuscript.

Funding: This study was supported by Territori Aperti, a project funded by the Fondo Territori Lavoro e Conoscenza of the Confederazione Generale Italiana del Lavoro, the Confederazione Italiana Sindacati Lavoratori, and the Unione Italiana del Lavoro.

Institutional Review Board Statement: Not applicable.

Informed Consent Statement: Not applicable.

Data Availability Statement: Publicly available datasets were analyzed in this study. This data can be found here: https: / / comtrade.un.org; https: / / data.imf.org/?sk=9d6028d4-f14a-464c-a2f2 -59b2cd424b85; http:/ / www.cepii.fr/CEPII/en/bdd_modele/presentation.asp?id=6; https:/ / lpi. worldbank.org.

Conflicts of Interest: The authors declare no conflict of interest. The opinions expressed in the paper are personal and do not necessarily reflect the views of the institutions to which the authors belong.

\section{References}

Anderson, James E. 1979. A Theoretical Foundation for the Gravity Equation. American Economic Review 69: 106-16. [CrossRef]

Anderson, James E. 2011. The Gravity Model. Annual Review of Economics 3: 133-60. [CrossRef]

Anderson, James E., and Eric Van Wincoop. 2003. Gravity with Gravitas: A Solution to the Border Puzzle. American Economic Review 93: 170-92. [CrossRef]

Anderson, Kym, and Hege Norheim. 1993. From Imperial to Regional Trade Preferences: Its Effect on Europe's Intra- and ExtraRegional Trade. Weltwirtschaftliches Archiv 129: 78-102. [CrossRef]

Baier, Scott L., and Jeffrey H. Bergstrand. 2009. Bonus Vetus OLS: A Simple Method for Approximating International Trade-Cost Effects Using the Gravity Equation. Journal of International Economics 77: 77-85. [CrossRef]

Baldwin, Richard, and Daria Taglioni. 2006. Gravity for Dummies and Dummies for Gravity EquationsGravity for Dummies and Dummies for Gravity Equations. London: Centre for Economic Policy Research, vol. 5850, pp. 1-23. [CrossRef]

Baniya, Suprabha, Nadia Rocha, and Michele Ruta. 2020. Trade Effects of the New Silk Road: A Gravity Analysis. Journal of Development Economics 146. [CrossRef] 
Bartley Johns, Marcus, Julian Latimer Clarke, Clay Kerswell, and Gerard McLinden. 2018. Trade Facilitation Challenges and Reform Priorities for Maximizing the Impact of the Belt and Road Initiative. MTI Global Practice Discussion Paper n.4. Washington: World Bank. [CrossRef]

Bergstrand, Jeffrey H. 1985. The Gravity Equation in International Trade: Some Microeconomic Foundations and Empirical Evidence. The Review of Economics and Statistics 67: 474. [CrossRef]

Bergstrand, Jeffrey H. 1989. The Generalized Gravity Equation, Monopolistic Competition, and the Factor-Proportions Theory in International Trade. The Review of Economics and Statistics 71: 143. [CrossRef]

Boffa, Mauro. 2018. Trade Linkages between the Belt and Road Economies. Policy Research Working Paper. Washington: World Bank. [CrossRef]

Constantinescu, Cristina, and Michele Ruta. 2018. How Old Is the Belt and Road Initiative? Long Term Patterns of Chinese Exports to BRI Economies. MTI Practice Note n.6. Washington: World Bank.

Das, Khanindra Ch. 2017. The Making of One Belt, One Road and Dilemmas in South Asia. China Report 53: 125-42. [CrossRef]

De Soyres, François, Alen Mulabdic, and Michele Ruta. 2020. Common Transport Infrastructure: A Quantitative Model and Estimates from the Belt and Road Initiative. Journal of Development Economics 143. [CrossRef]

De Soyres, François, Alen Mulabdic, Siobhan Murray, Nadia Rocha, and Michele Ruta. 2018. How Much Will the Belt and Road Initiative Reduce Trade Costs? International Economics 159: 151-64. [CrossRef]

Deardorff, Alan V. 1998. Determinants of Bilateral Trade: Does Gravity Work in a Neoclassical World? In The Regionalization of the World Economy. Chicago: University of Chicago Press, pp. 7-32.

Donaubauer, Julian, Alexander Glas, Birgit Meyer, Peter Nunnenkamp, Robert C Feenstra, Kijin Kim, Paul Mariano, and Euri Lee. 2018. The Belt and Road Initiative: Impact on Trade Patterns between China and Central Asia. Review of World Economics 154: 185-98. [CrossRef]

Drysdale, Peter, and Ross Garnaut. 1982. Trade Intensities and the Analysis of Bilateral Trade Flows in a Many-Country World: A Survey. Hitotsubashi Journal of Economics 22: 62-84. [CrossRef]

Eaton, Jonathan, and Samuel Kortum. 2002. Technology, Geography, and Trade. Econometrica 70: 1741-79. [CrossRef]

Feenstra, Robert C. 2004. Advanced International Trade: Theory and Evidence. Princeton: Princeton University Press.

Frankel, Jeffrey A. 1997. Regional Trading Blocs in the World Economic System. Washington: Institute for International Economics. [CrossRef]

Gaulier, Guillaume, Sébastien Jean, and Deniz Ünal-Kesenci. 2004. Regionalism and the Regionalisation of International Trade. CEPII Working Paper 2004-16. Available online: http:/ / www.cepii.fr/CEPII/en/publications/wp/abstract.asp?NoDoc=198 (accessed on 4 November 2020).

Grainger, Andrew, and Gerard McLinden. 2013. Trade Facilitation. In Handbook of Trade Policy for Development. Edited by Lukauskas Arvid, Stern Robert Mitchell, Stern Robert M. and Zanini Gianni. Oxford: Oxford University Press.

Herrero, Alicia Garcia, and Jianwei Xu. 2017. China's Belt and Road Initiative: Can Europe Expect Trade Gains? China and World Economy 25: 84-99. [CrossRef]

Hurley, John, Scott Morris, and Gailyn Portelance. 2018. Examining the Debt Implications of the Belt and Road Initiative from a Policy Perspective. Center for Global Development Policy Paper. Available online: https:/ / www.cgdev.org/publication/examining-debtimplications-belt-and-road-initiative-policy-perspective (accessed on 4 November 2020).

Hussain, Zahid, Nadia Hanif, Wasim Abbas Shaheen, and Muhammad Nadeem. 2019. Empirical Analysis of Multiple Infrastructural Covariates: An Application of Gravity Model on Asian Economies. Asian Economic and Financial Review 9: 299-317. [CrossRef]

Iapadre, P. Lelio, and Francesca Tironi. 2009. Measuring Trade Regionalisation: The Case of Asia. UNU-CRIS Working Papers 9: 57-86.

Iapadre, P. Lelio, and Lucia Tajoli. 2014. Emerging Countries and Trade Regionalization. A Network Analysis. Journal of Policy Modeling 36: S89-S110. [CrossRef]

Iapadre, P. Lelio. 2006. Regional Integration Agreements and the Geography of World Trade: Statistical Indicators and Empirical Evidence. In Assessment and Measurement of Regional Integration. Edited by De Lombaerde Philippe. London: Routledge, pp. 65-85. [CrossRef]

Kim, Kijin, and Paul Mariano. 2020. Trade Impact of Reducing Time and Costs at Borders in the Central Asia Regional Economic Cooperation Region. No. ADBI Working Paper Series 1106. Tokyo: Asian Development Bank Institute.

Kunaka, Charles, and Robin Carruthers. 2014. Trade and Transport Corridor Management Toolkit. Washington: The World Bank. [CrossRef]

Kunimoto, Kazutaka. 1977. Typology of Trade Intensity Indices. Hitotsubashi Journal of Economics 17: 15-32.

Leamer, Edward E., and Robert M. Stern. 1970. Quantitative International Economics. Chicago: Aldine.

Lee, Euri. 2018. The Belt and Road Initiative: Impact on Trade Patterns between China and Central Asia. East Asian Community Review 1: 185-98. [CrossRef]

Mayer, Thierry, and Soledad Zignago. 2012. Notes on CEPII's Distances Measures: The GeoDist Database. SSRN Electronic Journal. [CrossRef]

Metulini, Rodolfo, Roberto Patuelli, and Daniel A. Griffith. 2018. A Spatial-Filtering Zero-Inflated Approach to the Estimation of the Gravity Model of Trade. Econometrics 6: 9. [CrossRef]

Novy, Dennis. 2013. Gravity Redux: Measuring International Trade Costs with Panel Data. Economic Inquiry 51: 101-21. [CrossRef]

Patuelli, Roberto, Gert Jan M. Linders, Rodolfo Metulini, and Daniel A. Griffith. 2016. The Space of Gravity: Spatially Filtered Estimation of a Gravity Model for Bilateral Trade. Advances in Spatial Science, 145-69. [CrossRef] 
Pöyhönen, Pentti. 1963. A Tentative Model for the Volume of Trade between Countries. Weltwirtschaftliches Archiv 90: 93-100.

Ramasamy, Bala, and Matthew C.H. Yeung. 2019. China's One Belt One Road Initiative: The Impact of Trade Facilitation versus Physical Infrastructure on Exports. World Economy 42: 1673-94. [CrossRef]

Redding, Stephen J., and Matthew A. Turner. 2015. Transportation Costs and the Spatial Organization of Economic Activity. In Handbook of Regional and Urban Economics. Edited by Duranton Gilles, Henderson Vernon and Strange William. Amsterdam: Elsevier, pp. 1339-98.

Shaoshi, Xu. 2015. Vision and Actions on Jointly Building Silk Road Economic Belt and 21st-Century Maritime Silk Road. Beijing: China's National Development and Reform Commission.

Tinbergen, Jan. 1962. Shaping the World Economy: Suggestions for an International Economic Policy. New York: Twentieth Century Fund.

Yang, Gaoju, Xianhai Huang, Jiahui Huang, and Hangyu Chen. 2020. Assessment of the Effects of Infrastructure Investment under the Belt and Road Initiative. China Economic Review 60: 101418. [CrossRef]

Yotov, Yoto V., Roberta Piermartini, José-Antonio Monteiro, and Mario Larch. 2016. An Advanced Guide to Trade Policy Analysis: The Structural Gravity Model. Geneva: World Trade Organization. [CrossRef]

Yu, Chunjiao, Ren Zhang, Lian An, and Zhixing Yu. 2020. Has China's Belt and Road Initiative Intensified Bilateral Trade Links between China and the Involved Countries? Sustainability 12: 6747. [CrossRef]

Yu, Hong. 2017. Motivation behind China's ‘One Belt, One Road' Initiatives and Establishment of the Asian Infrastructure Investment Bank. Journal of Contemporary China 26: 353-68. [CrossRef]

Zhang, Jianhong, and Arjen Van Witteloostuijn. 2004. Economic Openness and Trade Linkages of China: An Empirical Study of the Determinants of Chinese Trade Intensities from 1993 to 1999. Review of World Economics 140: 254-81. [CrossRef] 